\title{
Sheep Lung Cytochrome P4501A1 (CYP1A1): cDNA Cloning and Transcriptional Regulation by Oxygen Tension
}

\author{
Thomas A. Hazinski, Edouard Noisin, Isabelle Hamon, and Andy DeMatteo \\ Department of Pediatrics, Vanderbilt University School of Medicine, Nashville, Tennessee 37232-2586
}

\begin{abstract}
Lung cytochrome $\mathbf{P 4 5 0}$ activity has been linked to neoplasia and may produce reactive oxidant species and potent arachidonic acid metabolites. In lamb lung, oxygen breathing increases lung P450 activity, and inhibition of lung cytochrome $\mathbf{P 4 5 0}$ activity reduces oxygen-induced lung injury. The P4501A1 (CYP1A1) isozyme is present in many lung cells, including endothelial cells, and may therefore be involved in the pathogenesis of hyperoxic injury to microvascular endothelium. Therefore, to test the hypothesis that oxygen regulates $P 4501 A 1$ gene expression in the lung, we cloned the sheep P4501A1 cDNA, and examined its regulation by oxygen tension in vivo and in vitro. We found that, in vivo, oxygen breathing significantly increased lung $P 4501 A 1$ RNA levels and that this increase preceded the increase in isozyme activity. Oxygen exposure also promptly increased P4501A1 RNA levels in cultured lamb lung microvascular endothelial cells but not in endothelial cells isolated from the main pulmonary artery or in lung smooth muscle cells. The oxygen-stimulated increase in P4501A1 RNA levels was not serum dependent, was unaffected by cycloheximide treatment, and could not be mimicked by treatment of the cells with oxygenated medium, conditioned medium, or by chemical oxidants. By nuclear run-on assay in cultured lung endothelial cells, oxygen increased the transcription rate of $P 4501 A 1$ by almost fourfold after $90 \mathrm{~min}$ of oxygen exposure but had no significant effect on P4501A1 RNA stability. We conclude that oxygen tension, but not chemical oxidants, increases P4501A1 gene expression pretranslationally in lung microvascular endothelial cells. We speculate that oxygen induction of $\mathbf{P 4 5 0}$ activity in these cells may contribute to microvascular injury during oxygen breathing. ( $\mathrm{J}$. Clin. Invest. 1995. 96:2083-2089.) Key words: pulmonary oxygen toxicity $\bullet$ cytochrome $P 4501 A I \cdot$ gene regulation $\cdot$ endothelial cell $\cdot$ hyperoxia
\end{abstract}

Address correspondence to Thomas A. Hazinski, M.D., Pediatric Pulmonary Medicine, Vanderbilt University, School of Medicine, Nashville, TN 37232-2586. Phone: 615-343-7617; FAX: 615-343-1763.

Received for publication 24 April 1995 and accepted in revised form 28 June 1995.

J. Clin. Invest.

(C) The American Society for Clinical Investigation, Inc.

0021-9738/95/10/2083/07 \$2.00

Volume 96, October 1995, 2083-2089

\section{Introduction}

Oxygen breathing increases the production of reactive oxygen species (ROS) ${ }^{1}$ in lung and increases lung microvascular permeability, but the sites and importance of specific ROS production pathways are uncertain $(1,2)$. Hyperoxia increases both mitochondrial and microsomal oxidant production in lung cells (3), and physiologic studies demonstrate that increased pulmonary microvascular permeability is an early indicator of oxygen injury (4). Several lines of evidence suggest that the pulmonary cytochrome P450 monooxygenases may be involved in hyperoxic lung injury. For example, in reconstituted systems, cytochrome $\mathrm{P} 450$ enzymes produce superoxide and hydrogen peroxide due to uncoupling of electron flow during the addition of molecular oxygen to a variety of substrates (5-7). In addition, some mouse strains increase their lung P450 enzyme activity upon exposure to hyperoxia, and these strains are highly susceptible to hyperoxic lung injury compared with strains that do not increase their lung P450 content in hyperoxia (8). In addition, rats given agents which reduce lung P450 content demonstrate decreased susceptibility to oxygen injury (9). Finally, we have shown that oxygen exposure increases lung P450 content in a lamb model of hyperoxic lung injury and that inhibition of P450 with either endotoxin or cimetidine pretreatment reduces pulmonary oxygen toxicity $(10,11)$.

One of the P450 isozymes in the lung of many species is the P4501A1 (Cyp1A1) isozyme (12-14). Therefore, to understand better the mechanism by which oxygen breathing increases lung P450 activity and to determine which lung cells are responsible for this increase, we cloned the P4501Al gene from a lamb lung cDNA library, measured steady state P4501AI RNA levels in lung tissue, in primary cultures of sheep lung endothelial cells, and in lung vascular smooth muscle cells. We found that, in vivo, oxygen breathing increased steady state P4501A1 RNA levels by over fourfold within $12 \mathrm{~h}$ of oxygen exposure and that this increase preceded the increase in P4501A1 enzyme activity. In cultured microvascular endothelial cells (but not in endothelial cells from the main pulmonary artery or in lung smooth muscle cells), oxygen exposure increased P4501A1 RNA levels within $6 \mathrm{~h}$, and this effect could not be mimicked by exposure of lung cells to chemical oxidants, to oxygenated medium, or to medium conditioned by exposure to hyperoxic cells. Nuclear run-off assays indicated that the oxygen-associated increase in P4501A1 RNA levels was due in

1. Abbreviations used in this paper: 3-MC, 3-methylcholanthrene; $\mathrm{AhR}$, aromatic hydrocarbon receptor; ROS, reactive oxygen species; XRE, xenobiotic response element. 
part to an increase in P4501A1 transcription rate. We concluded from these studies that oxygen tension increases lung microvascular P4501A1 gene expression and speculate that this effect may contribute to the oxidant stress of oxygen exposure.

\section{Methods}

Animal preparation, oxygen exposure protocol, and tissue analysis. These methods have been described previously (10, 11). Briefly, 2-4wk-old lambs were anesthetized and vascular catheters were inserted into a limb artery and vein. After $24 \mathrm{~h}$ of recovery, the lambs were placed into a wood and Plexiglas chamber which was maintained at $40 \%$ humidity and $20^{\circ} \mathrm{C}$. Either medical-grade air or $100 \%$ oxygen flowed into this chamber at rates of 8-12 liters/min, which was sufficient to maintain ambient $\mathrm{FIO}_{2}$ at $>0.95$ and $\mathrm{CO}_{2}$ tension at $<1$ torr. To maintain nutrition and hydration, the lambs were fed commercial infant formula three times per day via orogastric tube $\left(150 \mathrm{~cm}^{3} / \mathrm{kg} / \mathrm{d}\right)$, and samples of arterial blood were obtained every $12 \mathrm{~h}$. Lambs were injected with lethal intravenous doses of pentobarbital and lungs were obtained after $12,24,48,72$, and $96 \mathrm{~h}$. The left lung was perfused free of visible blood with cold phosphate-buffered saline and frozen at $-70^{\circ} \mathrm{C}$ for subsequent microsome and RNA isolation. These protocols were approved by the Vanderbilt Animal Care and Use Committee at Vanderbilt University.

Lung microsomes were isolated from blood-free lung by differential centrifugation (15) and P4501A1 isozyme activity was estimated as the deethylation of ethoxyresorufin (16). The protein concentration of lung microsomes was measured by the BCA method (17). P4501Al activity is expressed as the amount of product per minute per milligram of protein. Total lung RNA was isolated from the left upper lobe of all lambs using the method of Chomczynski (18).

cDNA cloning. poly (A) ${ }^{+}$RNA was isolated from the lung of a 3wk-old mixed breed lamb that had breathed oxygen for $48 \mathrm{~h}$. A cDNA bacteriophage library was constructed using Uni-ZAP XR (Stratagene, La Jolla, CA). The library was screened with a ${ }^{32} \mathrm{P}$-labeled (MultiPrime; Amersham Corp., Arlington Heights, IL) full-length rat P4501AI cDNA clone (kindly provided by $D$. Nebert, University of Cincinnati). After secondary screening, the insert DNA was isolated and subcloned into a plasmid vector (GEMEX-1 DNA; Promega, Madison, WI), restriction-mapped, and sequenced in both directions using both singlestranded (SEQUINASE; United States Biochemical Corp., Cleveland, $\mathrm{OH}$ ) and cycle sequencing (Circumvent; New England Biolabs Inc. Beverly, MA). Six unique clones were identified, one of which contained the full-length cDNA when compared with the rodent sequence The sheep cDNA sequence was entered into a DNA analysis program (DNASTAR, Inc., Madison, WI) and compared for sequence homology with other reported genes.

P4501A1 probes. A cDNA probe termed 70-2 was used in initia experiments. This consisted of a KpnI-BamH1 fragment containing almost the entire cDNA. This cDNA fragment was labeled by multipriming. Once the cDNA sequence was known, a 30-mer oligonucleotide designed from the $3^{\prime}$ untranslated portion of the cDNA was constructed and end labeled. We used this latter probe in in vitro studies to reduce the chance of detecting related P450 RNAs. Both probes gave equivalent results in Northern analysis.

RNA analysis (Northern and slot blots). Total lung RNA from lamb lung and from lung endothelial cells obtained after timed exposure to hyperoxia was isolated and quantitated spectrophotometrically. For slot blots, $2 \mu \mathrm{g}$ of each RNA sample was spotted onto filters using a vacuum apparatus (Schleicher \& Scheull, Inc., Keene, NH). For Northern blots, $4 \mu \mathrm{g}$ of RNA was loaded onto $1 \%$ agarose gels and electrophoresed. The RNA was then transferred to nylon membranes overnight. Hybridization conditions for both blotting procedures were as follows. Filters were crosslinked by brief ultraviolet exposure (Stratolinker; Stratagene, La Jolla, CA) and then placed in bags containing $20 \mathrm{ml}$ of prehybridization solution containing $5 \mathrm{ml}$ of $20 \times \mathrm{SSC}, 10 \mathrm{ml}$ formamide, $1 \mathrm{ml} 1 \mathrm{M}$
$\mathrm{NaPO}_{4}, 0.2 \mathrm{ml} 100 \times$ Dennhardts solution, and $3 \mathrm{ml}$ double-distilled sterile water. The filters were preincubated for $1 \mathrm{~h}$ at $37^{\circ} \mathrm{C}$, then the solution is removed and $10 \mathrm{ml}$ of hybridization solution (four parts prehybridization solution and one part $50 \%$ dextran sulfate) is added. Labeled cDNA or oligonucleotide probe $(\sim 1$ million $\mathrm{cpm} / \mathrm{ml}$ solution $)$ and an equal volume of salmon sperm DNA $(10 \mathrm{mg} / \mathrm{ml})$ were boiled for $5 \mathrm{~min}$ and then injected into the bag. The bags were placed in a $42^{\circ} \mathrm{C}$ water bath for $20 \mathrm{~h}$. The filters were washed four times at room temperature with $2 \times \mathrm{SSC} / 0.1 \%$ SDS for $5 \mathrm{~min}$, then twice at $55^{\circ} \mathrm{C}$ with $0.1 \times \mathrm{SSC} / 0.1 \% \mathrm{SDS}$ for $15 \mathrm{~min}$. The filters were then placed on film for 24-48 h (19). RNA abundance was estimated with a digital scanner and the filters were stripped and reprobed for the constitutive gene $\beta$-actin.

Relative RNA abundance was also estimated using the slot blot method. Results are expressed as relative densitometry units relative to the same filters probed for $\beta$-actin.

Endothelial cell isolation and oxygen exposure protocols. Endothelial cells from large pulmonary arteries were obtained by gently scraping the cells from large vessels directly into cell culture media (see below). Microvascular endothelial cells and smooth muscle cells were isolated from freshly isolated portions of peripheral blood-free lung of air-breathing lambs using the method of Meyrick et al. (20), except that Dulbecco's modified Eagle medium (DMEM) supplemented with $15 \mathrm{mg} / 400$ $\mathrm{ml}$ endothelial growth supplement (Collaborative Biomedical Products, Becton Dickinson, Bedford, MA) was used. In brief, to isolate microvascular endothelial cells, subpleural lung fragments were minced with small scissors and placed in DMEM to which is added $1 \mathrm{mg} / \mathrm{ml}$ collagenase type II (Worthington Biochemical Corp., Freehold, NJ). The solution was incubated at $37^{\circ} \mathrm{C}$ for $30 \mathrm{~min}$, then spun at $1,000 \mathrm{~g}$ for 10 min. The supernatant was discarded and the pellet was resuspended in supplemented DMEM containing 5\% calf serum (Hyclone Laboratories, Logan, UT), $0.5 \%$ penicillin/streptomycin, and $0.1 \%$ gentamycin. Aliquots of cells were added to $\mathrm{P}-100$ plates and incubated at $37^{\circ} \mathrm{C}$ in $21 \%$ air $15 \%$ carbon dioxide. Plates were examined daily and fresh medium was added. Cell types were initially identified by morphology, isolated with cloning rings, removed, replated onto plastic P-100 dishes, and covered with DMEM containing $5 \%$ fetal calf serum. The cells were incubated in $5 \% \mathrm{CO}_{2} / 95 \%$ air at $37^{\circ} \mathrm{C}$. After three to four passages, putative endothelial cells and smooth muscle cells were identified by morphology, subcloned into separate dishes, and also grown on plastic coverslips for immunofluorescent detection of Factor VIII (anti-vWf, anti-FVIII-RAG; and anti-mouse-fluorescein, $\mathrm{F}(\mathrm{Ab})$ fragment, both from Boehringer Mannheim Corp., Indianapolis, IN), LDL binding (LilAc-LDL; Biomedical Technologies, Inc., Stoughton, MA), and smooth muscle actin (monoclonal Anti- $\alpha$ smooth muscle actin; Sigma Immunochemicals, St. Louis, MO). Cells which stained positive for Factor VIII and LDL but negative for actin were considered to be endothelial cells and were studied further. Smooth muscle cells were also isolated from lung explants by morphology, subcloned, and tested by immunofluorescence. Cells which were negative for Factor VIII and LDL binding but positive for actin were considered to be smooth muscle cells.

We also performed preliminary studies to determine the effect of ambient oxygen concentration and serum concentration on endothelial cell growth. We placed the cells in serum-free media for $24 \mathrm{~h}$, then added bovine calf serum at concentrations from 0 to $5 \%$ and exposed the subconfluent cells to either air or oxygen for $48 \mathrm{~h}$. Then, we discarded the media, pelleted the trypsin/EDTA-treated cells by gentle centrifugation, resuspended them in fresh media, and counted cells in a Coulter counter (Coulter Corp., Hialeah, FL). We found no consistent effect of serum concentration or $48 \mathrm{~h}$ of hyperoxia on endothelial cell number. After $48 \mathrm{~h}$, oxygen exposure reduced cell number by $\sim 15 \%$.

Before oxygen exposure, the near-confluent cells were placed in serum-free media for $24 \mathrm{~h}$. Then, fresh media containing $1 \%$ fetal calf serum were added and the cells were exposed to either $5 \% \mathrm{CO}_{2} / 95 \%$ air or $5 \% \mathrm{CO}_{2} / 95 \%$ oxygen for up to $48 \mathrm{~h}$. Total RNA was isolated and steady state RNA levels were estimated by slot blotting, autoradiog- 

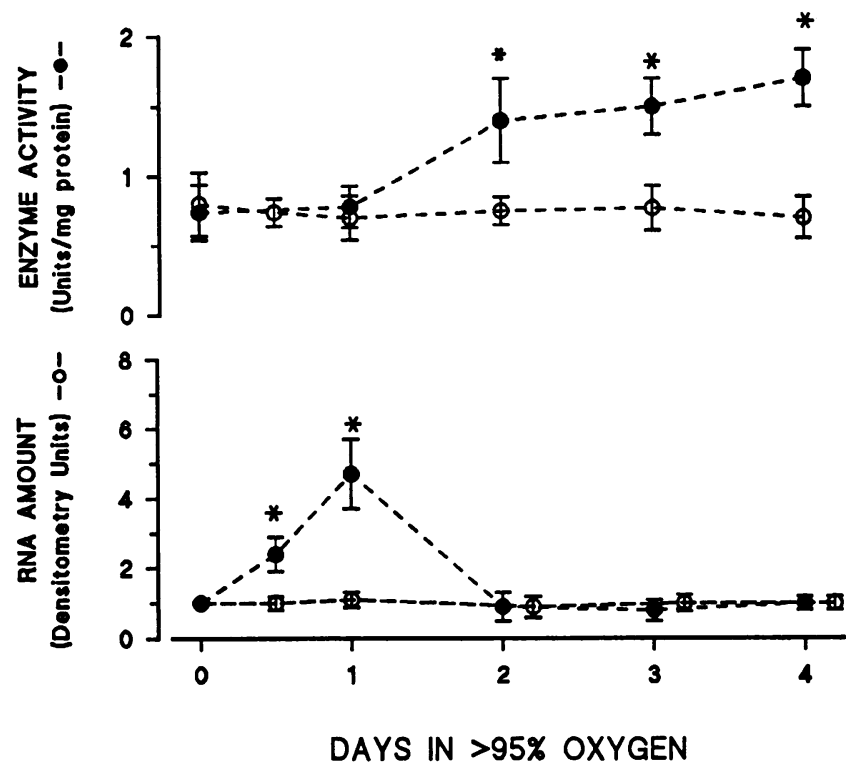

Figure 1. Effect of breathing $>95 \%$ oxygen on lamb lung P4501Al enzyme activity (top) and steady state RNA levels (bottom). Note that the significant increase in enzyme activity is preceded by an increase in RNA. Each data point represents the mean $\pm 1 \mathrm{SD}$ of values from three to six lambs. An asterisk indicates $P<0.02$ compared with air baseline value. Open circles, air-breathing lambs; closed circles, oxygen-breathing lambs.

raphy, and densitometry. P4501A1 RNA levels are expressed as arbitrary densitometry units relative to actin.

To test whether the effect of oxygen exposure on P4501Al gene expression was due to oxidation of media or serum components (21, 22 ), we bubbled medical grade $100 \%$ oxygen into DMEM $/ 1 \%$ fetal calf serum for $24 \mathrm{~h}$, then placed this medium on endothelial cells for up to $48 \mathrm{~h}$ in a $5 \% \mathrm{CO}_{2} / 95 \%$ air environment. To determine whether the effect of high oxygen tension on P4501Al gene expression was due to some soluble factor released by hyperoxic cells, media from cells exposed to $5 \% \mathrm{CO}_{2} / 95 \%$ oxygen for $24 \mathrm{~h}$ were removed and applied to fresh endothelial cell cultures and placed in a $5 \% \mathrm{CO}_{2} / 95 \%$ air environment for up to $48 \mathrm{~h}$.

To determine whether new protein synthesis was required for the hyperoxic effect, we added cycloheximide (Sigma Immunochemicals) $(1.25 \mu \mathrm{g} / \mathrm{ml})$ to the media before exposing the cells to hyperoxia.

To determine whether chemical oxidants could mimic the effect of oxygen tension, we added either tert-butyl hydroperoxide (Sigma Immunochemicals) or hydrogen peroxide (Fisher Scientific, Fair Lawn, $\mathrm{NJ})$ in concentrations between 10 and $300 \mu \mathrm{m}$ and grew these cells in $5 \% \mathrm{CO}_{2} / 95 \%$ air for up to $48 \mathrm{~h}$. Finally, we treated cultured cells with 3-methylcholanthrene (3-MC) (Sigma Immunochemicals) (0.1-1.0 $\mathrm{mM}$ ), a known inducer of P4501A1 at the transcriptional level (23).

To determine whether oxygen exposure increased P4501Al gene expression at the transcriptional level, we isolated endothelial cell nuclei after 90 min of exposure to either air or $95 \%$ oxygen and performed a nuclear run-on assay (24). As controls, DNA fragments from Bluescript plasmid, actin, and $\alpha$-tubulin were used, and transcription rate was estimated by scanning autoradiographs with a digital scanner.

To determine whether oxygen exposure influenced P4501Al RNA stability, lung endothelial cells were exposed to either air $/ 5 \% \mathrm{CO}_{2}$ or $95 \%$ oxygen $/ 5 \% \mathrm{CO}_{2}$ for $6 \mathrm{~h}$, then actinomycin-D $(0.005 \mathrm{mg} / \mathrm{ml}$ media $)$ and isolated RNA were added every $3-6 \mathrm{~h}$ for $18 \mathrm{~h}$. RNA was isolated and P4501AI levels were quantitated by slot blots and densitometry, then graphed on semi-log paper. Results were fitted to a log-linear curve.

Statistics. To assess the effects of air or oxygen exposure on

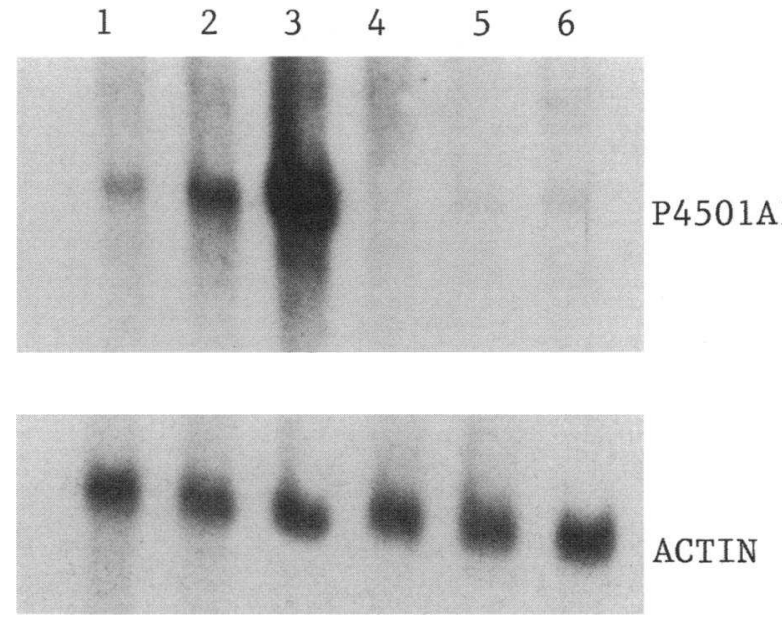

Figure 2. Representative Northern blot of total lung RNA from oxygenexposed lambs. Lanes $1-6$ depict RNA from individual lambs who

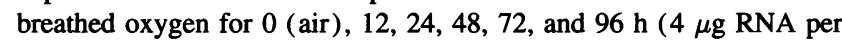
lane). The top row depicts the single $2.7-\mathrm{kb}$ band identified as P4501A1; the bottom row is the same filter stripped and reprobed for $\beta$-actin.

P4501Al enzyme activity and RNA amount, we used one-way ANOVA followed by multiple range testing. To assess the effects of serum concentration, oxygenated and conditional media, and treatment with tertbutyl hydroperoxide, hydrogen peroxide, cycloheximide, and 3-MC, we compared steady state RNA levels to air-exposed control flasks after 24 $\mathrm{h}$ of treatment using an unpaired $t$ test connected for multiple comparisons (25). In the table and figures, the results are the mean \pm 1 SD for three to six independent experiments. For drug treatment studies, the effect of the highest concentration of drug which did not affect cell viability is presented. All experimental results were confirmed in at least two different experiments; each experiment was performed at least three times.

\section{Results}

Oxygen tension increases lung P4501A1 RNA levels and enzyme activity in vivo. Using a heterologous P4501Al cDNA probe, we found that oxygen exposure significantly increased P4501A1 enzyme activity and this increase was preceded by a fourfold increase in steady state RNA levels within $24 \mathrm{~h}$ (Fig. 1). It is noteworthy that the increase in P4501Al RNA occurs $48 \mathrm{~h}$ before any physiologic or histologic evidence of lung injury $(10,11)$. In lamb lung tissue, a single RNA species of $\sim 2.6$ kb was identified (Fig. 2). Oxygen breathing had no effect on actin RNA levels (Fig. 2).

Description of sheep P4501A1 cDNA (Fig. 3). Our clone of the sheep P4501A1 cDNA was 2,586 bp in length and contained 105 bp of the $5^{\prime}$ untranslated region before two in-frame translation start sites. The $3^{\prime}$ untranslated region is $924 \mathrm{bp}$ in length from the TAG translation stop site to the polyadenylated tail. The $1,557 \mathrm{bp}$ cDNA open reading frame contains a consensus sequence for a heme-iron binding site at the expected region of the deduced protein sequence from amino acid 457 to 466 (26). Homology comparison shows that the sheep cDNA coding region is $85 \%$ homologous to human $1 \mathrm{~A} 1,82 \%$ to rat $1 \mathrm{~A} 1$, and $74 \%$ to human $1 \mathrm{~A} 2$.

Oxygen tension increases lung P4501A1 in lamb lung microvascular endothelial cells. As shown in Fig. 4, oxygen expo- 


$$
\text { ** SEQUENCE * * * * }
$$

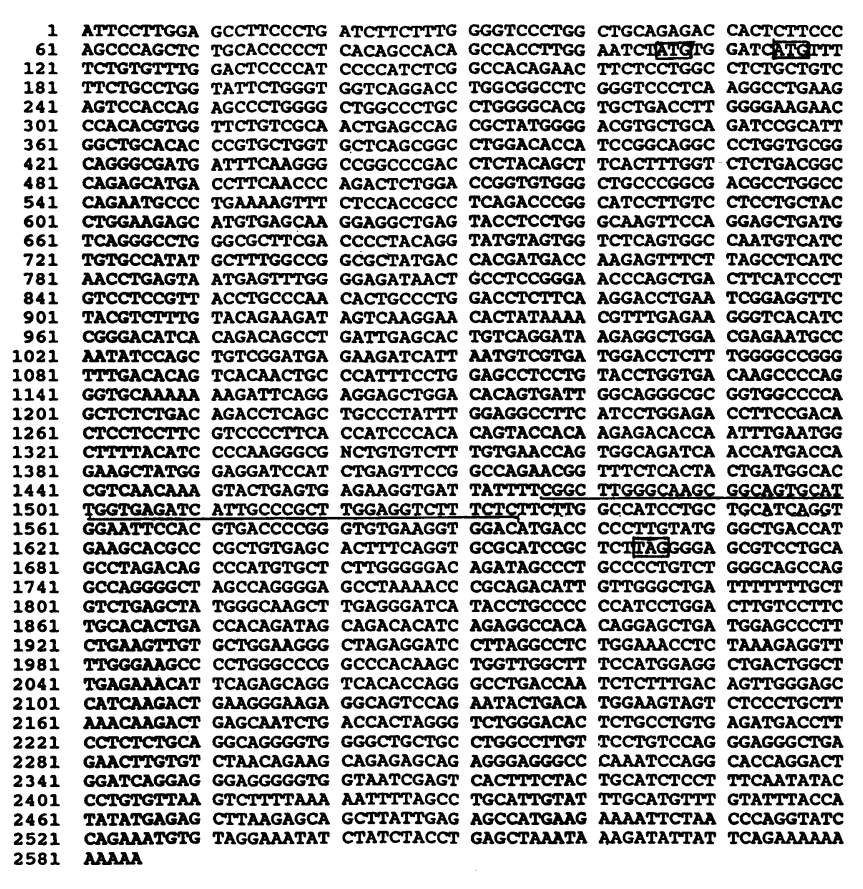

Figure 3. Lamb lung P4501A1 cDNA sequence. Boxes indicate translation start and stop sites; a putative heme-binding domain is underlined. See text for details.

sure significantly increased $P 4501 A 1$ gene expression within 6 $\mathrm{h}$ and was maximal after $24 \mathrm{~h}$; oxygen exposure had no effect on actin or $\alpha$-tubulin RNA levels. As shown in Fig. 5, there was no effect of serum concentration, oxygenated media, or media harvested from hyperoxic cells on P4501A1 RNA levels. Cycloheximide also had no effect on basal P4501Al gene expression and did not effect the response to oxygen exposure. Treatment of the cells with either the chemical oxidant tertbutyl hydroperoxide or hydrogen peroxide, over a range of concentrations (10-300 $\mu \mathrm{M})$ that did not affect cell viability, had no effect on steady state RNA levels. As expected, treatment of microvascular endothelial cells with 3-MC (a known inducer of P4501Al transcription) at concentrations up to $1 \mathrm{mM}$ significantly stimulated $P 4501 A 1$ gene expression. In two separate experiments, the effect of hyperoxia on 1A1 RNA accumulation was unaffected by changing the serum concentration from 0 to $5 \%$ (data not shown). The combination of 3-MC ( $1 \mathrm{mM})$ and hyperoxia resulted in a sixfold increase in P4501A1 levels after $24 \mathrm{~h}$ of exposure.

P4501Al RNA was barely detectable in pulmonary artery endothelial cells and in lung vascular smooth muscle cells after 5-7 d of autoradiography; no effect of hyperoxia could be detected (data not shown).

The effect of oxygen exposure on P4501Al transcription rate is shown in Table I. Oxygen exposure had no effect on transcription of the $\alpha$-tubulin or actin genes, but after $90 \mathrm{~min}$ of oxygen exposure the rate of initiation of new P4501A1 transcripts increased 3.6-fold relative to air exposure $(P<0.01)$.

Finally, oxygen tension had no effect on P4501A1 RNA stability. The $t_{1 / 2}$ under air conditions was $6.8 \pm 1.4$ and $5.9 \pm 1.6$ $\mathrm{h}$ under hyperoxic conditions (NS, $n=3, r=0.97-0.99$ ).

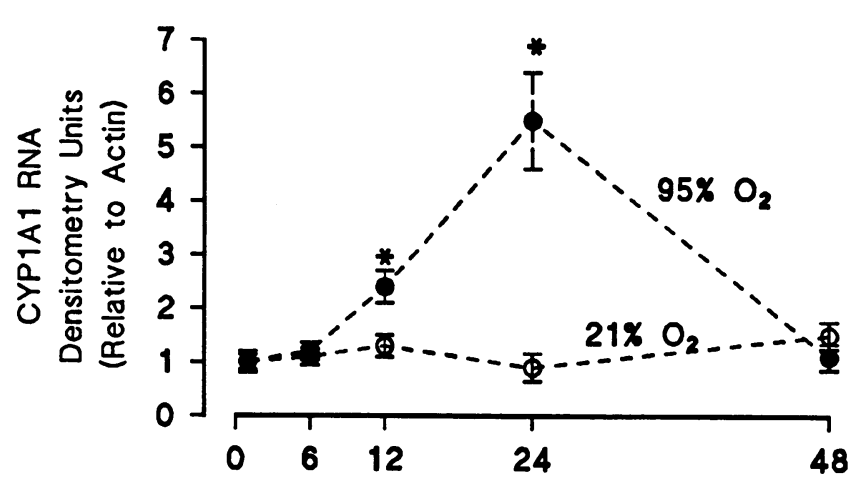

\section{HOURS IN $1 \%$ SERUM}

Figure 4. Oxygen exposure increases P4501Al RNA levels in sheep lung microvascular endothelial cells. Each point represents the mean \pm 1 $\mathrm{SD}$ of cells obtained from at least four individual lambs at each time. $* P<0.01$.

\section{Discussion}

We found that oxygen exposure in vivo significantly increases steady state lung P4501A1 RNA levels and enzyme activity in the lamb model of acute pulmonary oxygen toxicity. In this well-characterized model, oxygen breathing causes no net increase in lung antioxidant enzyme concentrations or in lung glutathione levels. In addition, there are no histologic or physiologic abnormalities in the lung until 60-72 h of oxygen breathing. After $72 \mathrm{~h}$ of hyperoxia, lung microvascular permeability to water and protein increases and the animals develop pulmonary edema and fatal respiratory failure $(10,11)$. Therefore, it is likely that the early increase in P4501A1 RNA levels and the subsequent increase in isozyme activity in the hyperoxic lung are the result of increased expression by lung cells in situ and not due either to the influx of inflammatory cells or to proliferation of resident lung cells.

A direct effect of oxygen tension on a specific lung cell population is also shown by our in vitro data. In cultured lamb lung microvascular endothelial cells, oxygen exposure significantly increased P4501A1 RNA levels by increasing transcription rate; RNA stability was unaffected by oxygen exposure. In these endothelial cells, oxygen-stimulated expression occurred as early as $6 \mathrm{~h}$, was not serum dependent, did not require protein synthesis, and could not be mimicked in vitro by hyperoxic media, conditioned media, or by two chemical oxidants. We interpret these data to indicate that oxygen tension regulates P4501A1 gene expression at the transcriptional level in the lung, and in particular, in the lung microcirculation.

For our in vitro experiments, we serum starved the cells for $24 \mathrm{~h}$ then added $1 \%$ bovine calf serum at the start of exposure to normoxic or hyperoxic conditions. Serum contains detectable catalase activity, and it is possible that the response to hydrogen peroxide or tert-butyl hydroperoxide was influenced by this serum effect. However, there was no effect of these oxidants on P4501A1 RNA levels even after $24-48 \mathrm{~h}$ and over a wide range of concentrations approaching toxicity. Moreover, the accumulation of P4501Al RNA after $24 \mathrm{~h}$ of hyperoxia was unaffected by serum concentrations which varied from 0 to $5 \%$ (data not shown). These findings make it unlikely that the cells 


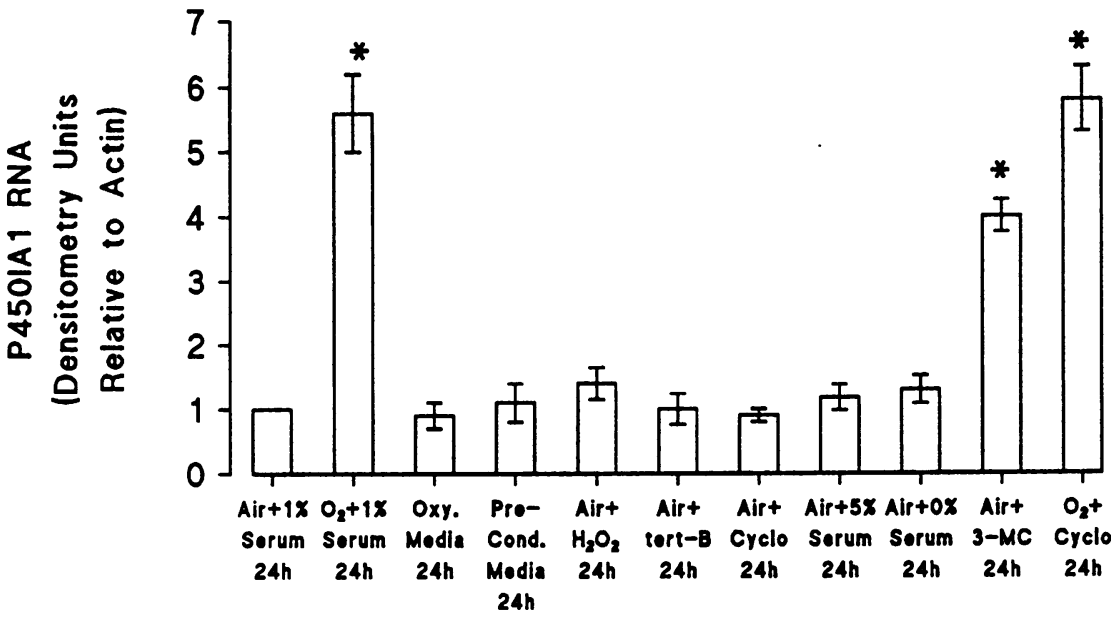

were protected from oxidant stress by the antioxidant properties of serum. We normalized our RNA results to $\beta$-actin expression which showed good interassay reproducibility and single clear bands on Northern blots (Fig. 2), and its abundance was unaffected by hyperoxia or by treatment with chemical oxidants.

Although regulation of eukaryotic gene expression by hypoxia (27) and by chemical oxidants (28) has been described, transcriptional regulation of gene expression by hyperoxia is rare (29). In the mouse lung, the surfactant protein B gene is increased by hyperoxia (30). Oxygen-induced lung injury in rabbits has also been shown to increase expression of a gene which encodes the tissue inhibitor of metalloproteinases, but this effect requires $96 \mathrm{~h}$ of oxygen exposure; by that time, there is histologic evidence of substantial inflammation and type II cell hyperplasia (31).

The mechanisms by which high oxygen tension regulates gene transcription are unknown. Hyperoxia could act by globally stimulating ROS production, which would then interact with trans-acting factors which bind to the antioxidant response element (32), or by influencing redox-sensitive genes like $f o s$, jun (33), or NF- $\kappa \mathrm{B}$ (34). However, because neither tert-butyl hydroperoxide nor hydrogen peroxide induced sheep $1 \mathrm{~A} 1$ gene expression even in concentrations which approached cell toxicity, our data thus far suggest that oxygen is inducing P4501A1 transcription by a mechanism other than ROS production. An alternative explanation is that hyperoxia is triggering a latent capacity for transcriptional activation in a constitutive factor, such as the oxidant-modified oxyR protein described in Escherichia coli (35). Another possibility is that hyperoxia is modi-

Table I. Effect of Oxygen Tension on P4501A1

Gene Transcription*

\begin{tabular}{lccc}
\hline Gene & Air & $95 \%$ Oxygen & $\mathrm{O}_{2}$ /Control \\
\hline P4501A1 & $24.2 \pm 3.1$ & $87.6 \pm 6.3^{\ddagger}$ & $3.6 \pm 0.3^{\ddagger}$ \\
$\alpha$-tubulin & $32.1 \pm 5.0$ & $20.5 \pm 8.2$ & $0.64 \pm 0.2$ \\
$\beta$-actin & $40.1 \pm 5.2$ & $38.6 \pm 6.4$ & $0.96 \pm 0.1$ \\
\hline
\end{tabular}

* Densitometry units corrected for PGEM control; $n=3-4 ;{ }^{\ddagger} P<0.02$. Microvascular endothelial cells were exposed to air or $95 \%$ oxygen for $90 \mathrm{~min}$, then nuclear run-on assay was performed as described.
Figure 5. Effect of oxygenated media, conditioned media, serum concentrations, chemical oxidants, cycloheximide, and 3-MC on P4501A1 RNA levels in sheep lung microvascular endothelial cells. Except for the hyperoxic cells, cells were treated for $24 \mathrm{~h}$ with each agent and kept in a $5 \% \mathrm{CO}_{2} /$ $21 \%$ oxygen environment. Abbreviations and doses: $\mathrm{H}_{2} \mathrm{O}_{2}$, hydrogen peroxide $(0.1 \mathrm{mM})$; tert$B$, tert-butylhydroperoxide $(0.1 \mathrm{mM}) ; C y c l o$, cycloheximide $(1.25 \mathrm{mg} / \mathrm{ml}$ media $) ; 3-M C$, 3 methycholanthrene $(1 \mathrm{mM})$. Each bar represents the mean $\pm 1 \mathrm{SD} ;{ }^{*} P<0.02$ compared with air control. fying a metalloprotein in lung microvascular endothelial cells which in turn directly or indirectly interact with an as yet undefined DNA regulatory element; this mechanism has been proposed for hypoxic regulation of the erythropoietin gene expression (36). We are now isolating the flanking regions of the sheep P4501A1 gene and preparing fusion gene constructs to test these possibilities.

The pulmonary expression of $P 4501 A 1$ enzyme activity has been linked to arachidonic acid and xenobiotic metabolism and to lung cancer (37-40). The P4501A1 isozyme is structurally and catalytically similar to $P 4501 A 2$, but this latter gene is not appreciably expressed in lung $(37,38)$. We cloned the P4501A1 cDNA from a sheep lung cDNA library, and its sequence shares greater homology with human $1 A 1$ than human $1 A 2$. In addition, our oligonucleotide $1 \mathrm{~A} 1$ probe was designed from the $3^{\prime}$ untranslated portion of the lamb lung $1 \mathrm{~A} 1 \mathrm{cDNA}$, making detection of other P450 RNA species unlikely. The unambiguous resolution of this possibility would require cloning of both the sheep 1A2 and 1B2 isozymes. However, we believe that we have cloned the sheep P4501A1 cDNA.

P4501A2 and perhaps 1B1 isozymes can metabolize ethoxyresorufin, and if either isozyme was present in sheep lung it would have contributed to the metabolic activity depicted in Fig. 1.

The transcriptional regulation of the $P 4501 A 1$ gene has been studied in detail $(39,40)$. The 5' flanking region of P4501Al contains multiple DNA sequences termed the xenobiotic response element (XRE) which permits transcriptional activation by phenolic hydrocarbons (37) which bind a cytosolic transcription activator termed the aromatic hydrocarbon receptor (AhR) (41). The endogenous ligand for this receptor is unknown, but the AhR and related nuclear binding proteins (42) result in transcriptional activation of $P 4501 A l$ by many polycyclic hydrocarbons including 3-MC and dioxins. In lamb lung microvascular endothelial cells, treatment with 3-MC increased steady state P4501A1 RNA levels by almost fourfold, suggesting that the AhR and its cofactors are present in these cells and that the sheep P4501Al gene contains at least one XRE. In human keratinocytes, P4501A1 is transcriptionally induced by subjecting the cells to physical stresses; physical stress also induced the transcription of other genes regulated by the AhR and XRE, suggesting that endogenous AhR ligands may be involved (43). 
Whether hyperoxia is acting as an environmental stress in lamb lung endothelial cells remains to be elucidated. In our study, it is possible that hyperoxia is increasing the availability of an endogenous ligand for the AhR. Recent studies have also suggested that the antioxidant response element and XRE are similar but the proteins which bind to them are not closely related (44).

It is noteworthy that the effect of oxygen tension on P4501Al gene expression was not evident in pulmonary artery endothelial cells or in lung smooth muscle cells. Whether the large vessel endothelial cells de-differentiate in culture or constitutively lack the relevant transcription factors is unknown, but our results provide another example of the site-specific nature of gene expression in pulmonary endothelial cells (45). Therefore, we conclude that the oxygen-associated increase in lung P4501A1 enzyme activity in vivo is strongly associated with overexpression in pulmonary microvascular endothelial cells. A physiologic role for P4501Al expression in the pulmonary microcirculation is unknown, but our whole animal studies clearly indicate that the induction of expression by hyperoxia is associated with microvascular injury in vivo. Additional evidence that P4501Al is linked to lung injury comes from the recent report of a P4501A2 knock-out mouse. P4501A2 is not present in mouse lung, but surprisingly pulmonary expression of the 1A1 isozyme was very high and the phenotype was lethal in $>99 \%$ of homozygotes; death was associated with pulmonary hypoplasia (46).

Our findings may have clinical relevance for patients undergoing oxygen therapy. If P4501Al enzyme activity is inducible in lung cells by oxygen and if microsomal oxidant production is increased, this would contribute to the oxidant stress of oxygen exposure, particularly in endothelial cells which are highly vulnerable to oxidant injury. In these cells, even small increases in ROS production could initiate peroxidation chain reactions adjacent to the endoplasmic reticulum if unopposed by antioxidants. Hyperoxic induction of P4501Al activity might also increase the production of potent epoxides from arachidonic acid which might further amplify hyperoxic lung injury. A better understanding of the enzymatic sources of ROS production in the lung could lead to the development of new strategies to reduce hyperoxic lung injury. Our findings may also provide further stimulus to understand the mechanisms by which ambient gases regulate gene expression.

\section{Acknowledgments}

The authors gratefully acknowledge the technical expertise of Sandra West.

This work was supported by National Institutes of Health grant HL14214-23 (Newborn Pulmonary SCOR).

\section{References}

1. Deneke, R. M., and B. L. Fanburg. 1980. Normobaric oxygen toxicity of the lung. N. Engl. J. Med. 303:76-86.

2. Cross, C. E. 1987. Oxygen radicals and human disease. Ann. Intern. Med. 107:526-545

3. Turrens, J. F., B. A. Freeman, and J. D. Crapo. 1982. Hyperoxia increases $\mathrm{H}_{2} \mathrm{O}_{2}$ release by lung mitochondria and microsomes. Arch. Biochem. Biophys. 217:411-421.

4. Crapo, J. D. 1986. Morphologic changes in pulmonary oxygen toxicity. Annu. Rev. Physiol. 48:721-731.

5. Ekström, G., and M. Ingelman-Sundberg. 1984. Cytochrome P450-depen- dent lipid peroxidation in reconstituted membrane vesicles. Biochem. Pharmacol. 33:2521-2523.

6. Dolphin, D. 1988. The generation of radicals during the normal and abnormal functioning of cytochromes P450. Basic Life Sci. 49:491-500.

7. Vaz, A. D. N., E. S. Roberts, and M. J. Coon. 1988. Radical intermediates in the catalytic cycles of cytochrome P450. Basic Life Sci. 49:501-507.

8. Gonder, J. C., R. A. Proctor, and J. A. Will. 1985. Genetic differences in oxygen toxicity are correlated with cytochrome P450 inducibility. Proc. Natl. Acad. Sci. USA. 82:6315-6319.

9. Kikkawa, Y., S. Yano, and L. Skoza. 1984. Protective effect of interferon inducers against hyperoxic pulmonary damage. Lab. Invest. 50:62-71.

10. Hazinski, T. A., M. France, K. A. Kennedy, and T. N. Hansen. 1989. Cimetidine reduces hyperoxic lung injury in lambs. J. Appl. Physiol. 67:24862492.

11. Hazinski, T. A., K. A. Kennedy, M. France, and T. N. Hansen. 1988. Pulmonary oxygen toxicity in young lambs: physiological and biochemical effects of endotoxin infusion. J. Appl. Physiol. 65:1579-1585.

12. Murray, G. I., T. S. Barnes, H. F. Sewell, S. W. B. Ewen, W. T. Melvin, and M. D. Burke. 1988. The immunocytochemical localization and distribution of cytochrome P-450 in normal human hepatic and extrahepatic tissues with a monoclonal antibody to human cytochrome P-450. Br. J. Clin. Pharmacol. 25:465-475.

13. Minchin, R. F., and M. R. Boyd. 1983. Localization of metabolic activation and deactivation systems in the lung: significance to the pulmonary toxicity of xenobiotics. Annu. Rev. Pharmacol. Toxicol. 23:217-238.

14. Serabjit-Singh, C. J., S. J. Nishio, R. M. Philpot, and C. G. Plopper. 1988. The distribution of cytochrome P-450 monooxygenase cells in the rabbit lung: an ultrastructural immunocytochemical characterization. Mol. Pharmacol. 33:279-289.

15. Matsubara, T., R. A. Prough, M. D. Burke, and R. W. Estabrook. 1974. The preparation of microsome fractions of rodent respiratory tract and their characterization. Cancer Res. 34:2196-2203.

16. Burke, M. D., and R. T. Mayer. 1974. Ethoxyresorufin: direct fluorometric assay of a microsomal $o$-dealkylation which is preferentially inducible by 3methylcholanthrene. Drug Metab. Dispos. 2:583-588.

17. Smith, P. K., R. I. Krohn, G. T. Hermanson, A. K. Mallia, F. H. Gartner, M. D. Provenzano, E. K. Fujimoto, N. M. Goeke, B. J. Olson, and D. C. Klenk. 1985. Measurement of protein using bicinchoninic acid. Anal. Biochem. 150:7685.

18. Chomczynski, P., and N. Sacchi. 1987. Single-step method of RNA isolation by acid guanidinium thiocyanate-phenol chloroform extraction. Anal. Biochem. 162:156-159.

19. Brown, T. 1993. Analysis of RNA by Northern and slot blot hybridization. Section 4.9.1 In Current Protocols in Molecular Biology. F. M. Ausubel, R. Brent, R. E. Kingston, D. D. Moore, J. G. Seidman, J. A. Smith, and K. Struhl, editors. Greene Publishing Associates, Inc. and John Wiley \& Sons, Inc., New York

20. Meyrick, B., R. Hoover, M. R. Jones, L. C. Berry, and K. L. Brigham. 1989. In vitro effects of endotoxin on bovine and sheep lung microvascular and pulmonary artery endothelial cells. J. Cell. Physiol. 138:165-174.

21. Paine, A. J. 1976. Induction of benzo[a]pyrene mono-oxygenase in liver cell culture by the photochemical generation of active oxygen species. Biochem. J. 158:109-117.

22. Rannug, A., U. Rannug, H. S. Rosenkranz, L. Winqvist, R. Westerholm, E. Agurell, and A. Grafström. 1987. Certain photooxidized derivatives of tryptophan bind with very high affinity to the Ah receptor and are likely to be endogenous signal substances. J. Biol. Chem. 262:15422-15427.

23. Jaiswal, A. K., F. J. Gonzalez, and D. W. Nebert. 1985. Human $P^{1}-450$ gene sequence and correlation of mRNA with genetic differences in benso[a]pyrene metabolism. Nucleic Acids Res. 13:4503-4520.

24. Greenberg, M. E. 1993. Identification of newly transcribed RNA. Section 4.10.1 In Current Protocols in Molecular Biology. F. M. Ausubel, R. Brent, R. E. Kingston, D. D. Moore, J. G. Seidman, J. A. Smith, and K. Struhl, editors. Greene Publishing Associates, Inc. and John Wiley \& Sons, Inc., New York.

25. Hintze, J. L. 1990. Number Cruncher Statistical System Version 5.03. Kaysville, UT. 442 pp.

26. Gotoh, O., Y. Tagashira, T. Iizuka, and Y. Fukii-Kuriyama. 1983. Structural characteristics of cytochrome P-450. Possible location of the heme-binding cysteine in determined amino-acid sequences. J. Biochem. 93:807-817.

27. Blanchard, K. L., A. M. Acquaviva, D. L. Galson, and H. F. Bunn. 1992. Hypoxic induction of the human erythropoietin gene: cooperation between the promoter and enhancer, each of which contains steroid receptor response elements. Mol. Cell. Biol. 12:5373-5385.

28. Rushmore, T. H., M. R. Morton, and C. B. Pickett. 1991. The antioxidan responsive element: activation by oxidative stress and identification of the DNA consensus sequence required for functional activity. J. Biol. Chem. 266:1163211639.

29. Fanburg, B. L., D. J. Massaro, P. A. Cerutti, D. B. Gail, and M. A. 
Berberich. 1993. Regulation of gene expression by $\mathrm{O}_{2}$ tension. Am. J. Physiol. Conference report. L235-L241.

30. Wikenheiser, K. A., S. E. Wert, J. R. Wispé, M. Stahlman, M. D'AmoreBruno, G. Singh, S. L. Katyal, and J. A. Whitsett. 1992. Distinct effects of oxygen on surfactant protein B expression in bronchiolar and alveolar epithelium. Am. J. Physiol. 262:L32-L39.

31. Veness-Meeham, K. A., E. R. Cheng, C. E. Mercier, S. L. Blixt, C. J. Johnston, R. H. Watkins, and S. Horowitz. 1991. Cell-specific alterations in expression of hyperoxia-induced mRNAs of lung. Am. J. Respir. Cell Mol. Biol. 5:516-521.

32. Rushmore, T. H., M. R. Morton, and C. B. Pickett. 1991. The antioxidant responsive element. Activation by oxidative stress and identification of the DNA sequence required for functional activity. J. Biol. Chem. 266:11632-11639.

33. Abate, C., L. Patel, F. Rauscher, and T. Curran. 1990. Redox regulation of fos and jun DNA binding activity in vitro. Science (Wash. DC). 249:457461.

34. Schreck, R., K. Albermann, and P. A. Baeuerle. 1992. Nuclear factor $\kappa B$ an oxidative stress-responsive transcription factor of eukaryotic cells (a review) Free Rad. Res. Commun. 17:221-237.

35. Demple, B., and C. F. Amabile-Cuevas. 1991. Redox redux: control of oxidative stress responses. Cell. 67:837-839.

36. Goldberg, M. A., S. P. Dunning, and H. E. Bunn. 1988. Regulation of the erythropoietin gene: evidence that the oxygen sensor is a heme protein. Science (Wash. DC). 242:1412-1415

37. Nebert, D. W., and J. E. Jones. 1989. Regulation of the mammalian cytochrome $\mathrm{P}^{1}-450$ (CYP1A1) gene. Int. J. Biochem. 21:243-252.

38. Ioannides, C. 1990. Induction of cytochrome P450I and its influences in chemical carcinogenesis. Biochem. Soc. Trans. 18:32-34.
39. Capdevila, J. H., A. Karara, D. Waxman, M. V. Martin, J. Falck, and F. P. Guenguerich. 1990. Cytochrome P-450 enzyme-specific control of the regio- and enantiofacial selectivity of the microsomal arachidonic acid epoxygenase. J. Biol. Chem. 265:10865-10871.

40. Kouri, R. E., C. E. McKinney, D. J. Solmiany, D. E. Snodgrass, N. P. Wray, and T. L. McLemore. 1982. Positive correlation between high aryl hydrocarbon hydroxylase activity and primary lung cancer as analyzed in cryopreserved lymphocytes. Cancer Res. 42:5030-5037.

41. Burback, K. M., A. Poland, and C. A. Bradfield. 1992. Cloning of the Ah-receptor cDNA reveals a distinctive ligand-activated transcription factor. Proc. Natl. Acad. Sci. USA. 89:8185-8189.

42. Reyes, H., S. Reisz-Porszasz, and O. Hankinson. 1992. Identification of the Ah receptor nuclear translocator protein (Amt) as a component of the DAN binding form of the Ah receptor. Science (Wash. DC). 256:1193-1195.

43. Savas, U., K. K. Bhattacharyya, M. Christou, D. L. Alexander, and C. R. Jefcoate. 1994. Mouse cytochrome P450EF, representatives of a new 1B subfamily of cytochrome P-450s. Cloning, sequence determination, and tissue expression. J. Biol. Chem. 269:14905-14911.

44. Pimental, R. A., B. Liang, G. K. Yee, A. Wilhelmsson, L. Poellinger, and K. E. Paulson. 1993. Dioxin receptor and C/EBP regulate the function of the glutathione S-transferase Ya gene xenobiotic response element. Mol. Cell. Biol. 13:4365-4373.

45. Scott, P. A. E., and R. Bicknell. 1993. The isolation and culture of microvascular endothelium. J. Cell Sci. 105:269-273.

46. Pineau, T., P. Fernandez-Salguero, S. S. Lee, T. McPhail, J. M. Ward, and F. J. Gonzalez. 1995. Neonatal lethality associated with respiratory distress in mice lacking cytochrome P450 1A2. Proc. Natl. Acad. Sci. USA. 92:51345138 . 